\title{
English Cultural Expressions Translation: Strategies Used in Rendering Narnia Chronicles into Arabic
}

\author{
Hussein Ali Habtoor \\ Department of English, Aden University, Yemen \\ Abrar Abdullah Al-Qahtani \\ Department of English, Najran University, KSA
}

\begin{abstract}
This study explores the intercultural transfer that takes place during the process of translating children's literature from English into Arabic. It's main purpose is to investigate how culture-specific items or expressions are dealt with when they are rendered into Arabic and find out the most preferable translation strategies that can be applied in an attempt to make the translated versions acceptable and accessible to the target audience. This study draws its data from three English novels that belong to the famous series of Narnia Chronicles which are translated into Arabic. It also states the effects of following domestication or foreignization translation strategies. It is found that there is no consistency in the used translation strategies despite the fact that the three books are translated by the same translator. The study also shows that a compromise which includes the use of domestication and foreignization translation strategies seems to be the ideal solution.
\end{abstract}

Index Terms — children's literature, culturally-bound expressions, translating strategies, language and culture

\section{INTRODUCTION}

To some extent, writing for children is marginalized in the Arab world in spite of the recent attempts to change its peripheral position. Most of literary works tend to be for adults as children are not given much attention in this part of the world which opens the door to introducing the Arab and Muslim Children to various western books through translation. The fact that the original texts belong to a language and culture that hold great dissimilarities with those of the target readers makes the process of translation very challenging. This is so because the act of translating foreign children's literature can allow a great deal of values, beliefs, concepts and baleful themes to be transferred into young readers. Furthermore, the moralizing and educating role allocated for children's books in the Arab world can make the translator's mission tiresome. Therefore, the current study is intended to concentrate on the translation of children's literature in the Arab world with special reference to fantasy novels represented by three selected books which belong to the series of Narnia Chronicles that seems to be full of intricate expressions to be translated.

\section{A. Statement of the Problem}

Translation provides a good chance for cultural transfer to take place. If the source culture and the target one have little in common, translators will face great challenges in a bid to produce a high- quality translation. Novels tend to be full of cultural items that are difficult to be dealt with during the process of translation because they have different values or are missing in the host culture. These cultural-bound expressions need to be rendered in a way that conforms to the norms and conventions of the receptive culture especially if the target readers are children who are immature and have limited knowledge. In addition, the creativity and aesthetic values of the source text must be taken into consideration in order for young readers to enjoy their reading experience. Little attention has been given to the translated children's literature in the Arab world in general and the difference between cultural invasion and crosscultural interaction in particular. Consequently, a considerable number of translated children's books may not reach the desired level of quality.

\section{B. Significance of the Study}

The majority of the available research studies that deal with translating literary works for children are mainly focused on following either foreignization translation strategies only or domestication translation strategies. There are other studies which consider the applied translation procedures by the translator without suggesting any kind of solutions that can be used to reach a compromise. This study will show the strengths and weaknesses of the Arabic translated versions, proposing some solutions to resolve the long-standing dilemma. What adds to the significance of this research study is the fact that Narnia chronicles are suggested as being allegories for Christian faith (Cicere, 2015). Filming these three 
novels beside their availability on the shelf of international children's literature contribute a lot to their worldwide influence.

\section{REVIEW OF LITERATURE}

\section{A. Cultural Translation}

It is clear that culture holds close connections to translation. Actually, translation helps various communities to become familiar with 'otherness' and peculiarities found in other societies. Aixelá (1996) argued that culture occupies a major place in translation due to the fact that there are some terms that have either different values in the receptor culture or do not exist at all. Such kinds of references are referred to as culture-specific terms (Elewa 2015, 49). They can be defined as words or phrases that refer to objects and ideas familiar to a particular cultural group but not beyond. These items are considered problematic by many translation scholars since their literal translation may be too exotic to target language readers. In addition, he (ibid, 44) stresses that a word can indicate a positive concept in one culture, but may indicate quite the opposite in another. For instance, "moon"' signifies women's beauty for Arabs. In contrast, English people associate it with paleness. Another example is the Arabs' frequent use of the phrase "Insha Allah" or "God willing" which has multiple functions other than indicating belief in predestination. If the previous phrase is translated literally, it will probably not be understood by target audience due to its reflection of a cultural pattern widespread in the Arab-speaking communities (ibid, 46-47). Hence, translators have become aware of the inadequacy of the linguistic approaches in addressing issues that go beyond the text. As a result, translation studies move from mere focus on linguistic approaches towards taking into account the cultural factors during the translation process. This shift to cultural aspects of translation is called "a cultural turn" by (Bassnett, 2002). Nida (2001) affirms that biculturalism is even more important than bilingualism as words only have meanings in terms of the cultures in which they function. Thus a truly successful translation will be achieved. Obviously, cultural translation takes into consideration the vital role of context in fleshing out the meaning. For Malinowski (1923) the meaning of utterances comes from the situational context in which they take place and not from the ideas of the words which constitute them.

It can be argued that a great significance is given to two opposing translation strategies when discussing how culturespecific items should be treated. These are foreignisation and domestication translation strategies which are distinguished by (Venuti, 1995). The former one is aimed at preserving the strangeness of the source culture in an effort to bring it close to that of the readers. However, the latter refers to the attempt to translate the source text in a transparent way. This means, minimising the foreign culture as much as possible in order for the target text to be accessible to the target audience. The application of these strategies in novel translations is said to have bonds with the intention behind the translation. For instance, in some texts, foreignisation translation strategies may be followed for the sake of introducing others' cultures to the target audience. Nonetheless, readers' expectations and needs should be fulfilled which can result in forcing the translator to adopt a particular strategy during the process of translation. It is worth noting that people who belong to totally different cultures may not be tolerant enough towards the content of the concrete text. Thus it should be handled in a specific manner (Wanh, 2014).

\section{B. A Brief Introduction to the Source Texts}

Arguably the most influential Christian writer of the 20th century, Clive Staples Lewis has a wide range of books. Nonetheless, The Chronicles of Narnia that refer to a series of seven high fantasy novels are probably his most popular writings and they are translated into Arabic by Saeed Baz. Lewis is a medieval literature specialist at Magdalen College, Oxford for most of his life. He abandons his childhood Christian faith and becomes an atheist for a long time, yet he returns to Christianity later on. He also becomes a member of the Church of England. He starts writing Narnia novels after the end of the war which becomes visible in some of his writings (Russel, 2009).

\section{a. The Lion, the Witch and the Wardrobe}

This novel is published in 2000 and it is translated into Arabic as "الأسد و الساحرة وخز انة الملابس . It is about Pevensie children who are sent away from London to live with Professor Kirke during World War II. The children explore the house on a rainy day and Lucy finds an enchanted wardrobe through which she enters into a strange snowy wood. She meets the Faun Tumnus who is amazed to meet a human girl. Later on, the Faun bursts into tears and admits that he is a servant of the evil White Witch. The Witch enchants Narnia so that it is always winter and never Christmas. When she leaves Narnia, she tells her siblings about her adventure but they do not believe her. One day, Edmund follows Lucy and he can enter Narnia. He meets the White Witch who introduces herself as the Queen of Narnia. She feeds Edmund enchanted Turkish Delight which gives him an insatiable desire for the dessert and she tries to convince him to let his siblings meet her. All the four children enter Narnia and they decide to unite with Aslan and defeat the White Witch. However, Edmund looks for the Witch to warn her of Aslan's arrival. The children discover that Aslan must sacrifice himself to atone for Edmund's treachery. Finally, when all seems lost, Aslan is reborn and leads the children and the good inhabitants of Narnia to victory. Later on, the four siblings rediscover the wardrobe, and they become children once again.

b. Prince Caspian.

Prince Caspian is published in 2000 and it is translated into Arabic as "الأمير كاسبيان" . The story of this novel starts when the four children are waiting for the train to go to their school. However, they are magically transported from 
England to Narnia world where they are faced by a lot of challenges. Later on, they meet the red dwarf named Trumpkin that tells them about what happen in Narnia after their leaving. During the absence of Narnia rulers, Telmarines invade it. Consequently, true Narnians hide in the woods. The prince Caspian used to live with his uncle King Miraz in a castle that is located in the middle of Narnia. There, he comes to know a lot about the old Narnia from his nanny who tells him a lot of things during bedtime. When his uncle knows about his wish to live in the old Narnia where a lot of talking animals are found, he decides to kill him. After that, battles are fought and Caspian's side keeps on losing. Hence, he is encouraged to use the horn whose magic brings the four human siblings back into Narnia. After listening to the dwarf's story, the four children decide to meet prince Caspian in Aslan's How where many of old Narnians used to hide. Later on, a great battle takes place between Peter and Miraz which ends in Narnians conquering the Telmarines and Caspian being the king of Narnia. Lastly, Peter, Lucy, Susan and Edmund return to their real world through invisible doors.

\section{c. The Voyage of the Dawn Treader}

The Voyage of the Dawn Treader is published in 2000 and it is translated into Arabic as"رحلة جو ابة الفجر In this novel, Lucy, Edmund and their cousin Eustace are transported into the magical world of Narnia through a painting of a ship. The three children find themselves next to a sailing ship named The Dawn Treader that is built by Caspian in an attempt to find seven missing lords. When the Dawn Treader stops for the first time, the main characters are kidnapped and Caspian is sold to one of the noblemen who turns to be one of the missing lords. Caspian ultimately can re-establish Narnian lordship over the isles and abolish the slave trade there. After that, the crew endures several days of stormy weather before landing on an island where Eustace is enchanted and turned into a dragon. It is discovered that one of the lost lords dies in a dragon form through examining the bracelet that Eustace used to put on. Later on, Aslan can change Eustace back into a human boy through tossing him into a pool of healing water. Next, they arrive at a deserted island where they find a golden statue of one of the missing lords at the bottom of an enchanted pool. Then, the Dawn Treader lands on an Island where no people are visible yet there are some signs of civilization. They are met by the Duffers who tell them that they are made ugly by a magician. Therefore, they make themselves invisible. Lucy goes to the house of the magician and finds the right spell to reverse their invisibility. The crew is navigating when they rescue one of the lost lords from an island where actual dreams including nightmares will come true. The final three lords are discovered on one of the islands where they are under an enchanted sleep. Finally, the crew accomplishes their mission, Caspian returns to Narnia and the children are sent back to their world by Aslan.

\section{The Importance of Translation in the Arab World.}

A plethora of translated works tend to bestow the original ones further prosperity for the fact that such works will enjoy a wider readership when translated. Marginality may be the fate of a wide range of civilisations if they do not allow interaction with others to take place with the help of various means such as translation. A case in point is the welcoming attitude that is embraced by the Arabic culture towards the contributions of other cultures. A great deal of Greek and Indian scientific as well as philosophical works is translated into Arabic which results in considerable developments in different fields. In addition, translation plays a key role in spreading Islam as prophet Muhammad, peace be upon him, used to look for translators who can render his letters into other languages in an effort to let nonMuslims convert to the new religion. Furthermore, the meanings of the Holy Qur'an are translated to non-Arabs in order for the message of Islam to be clear for them. Translation activities are noticed to reach its zenith during the Abbasid period which in turn helps to establish a new system of thought that becomes the foundation of the Arabic-Islamic culture. Realising the significance of translated materials in enriching various aspects of knowledge within the Arab world leads to the establishment of different organisations specialised in translation in an attempt to allow the Arabic readers to have a wider access to numerous works (Mehawesh, 2014).

\section{Related Works}

It is worth mentioning that there is a scarcity of research related to children's translated literature in the Arab World, yet there are some attempts to enhance people's awareness of such a vital issue. In his article, Madallel (2003) is basically concerned with translating children's literature in the Arab World. He analyses Al-Hajji's Bibliographical Guide to Arab Children's Books and finds that morality and didacticism are main themes of Arab children's literature. Furthermore, he argues that writing and translating for children is subject to many constraints especially if the source culture and the target one have nothing or little in common. Therefore, he is in favour of adopting some protective cultural measures during the process of translation into Arabic.

Exploring mistranslations caused by cultural and ideological differences between Arab and foreign cultures is Atiyya's main interest in her MA thesis (2010). She chooses Defoe's Robinson Crusoe as a Case Study. The analysis shows that although translators follow various translation strategies to bridge the gap between the source culture and the target one, they seem to neglect the unsuitability of many source text ideologies for the target readers. Moreover, it is found that gender and age should be taken into consideration when transferring an adult's text into one for children.

In the same vein, Dukmak (2012) analyses three books from the famous series of Harry Potter and their Arabic published translations, translated by three different translators, in order to reveal their translation norms. Her main concern is to investigate the treatment of cultural references, names, wordplay in the translation of children's literature 
into Arabic. The end results demonstrate that there is no coordination between the three official translators and their translation norms fluctuate between adequacy and acceptability.

Believing in the necessity of adaptation in translating children's literature, Ratiba (2014) investigates to what extent adaption can be considered as a reliable translation technique and the difficulties associated with following such a strategy. The researcher analyses the translation of the short story "The Rose Tree" into Arabic and the findings manifest the importance of adapting children's books during the process of translation, as the constraints of the target culture should be taken into consideration and the recipients' ethical values must be preserved. The extent to which the original text should be modified varies according to the translator's view and how childhood is recognised. Nonetheless, there are some cases where adaptations can be seen unnecessary or negative.

\section{ReSEARCH Methodology}

\section{A. The Data}

This study draws its data from three English novels that are translated into Arabic By Saeed Baz and are published in 2006 by Ophir (Amman, Jordan). These books belong to a series known as "The Chronicles of Narnia" that is written by C.S Lewis. The first book is titled "The Lion, The Witch and The Wardrobe" and it is translated as " الأسد والساحرة "وخزانة الملابس the other two books where the beginning of the story takes place. The other two books are known as "Prince Caspian" and" The Voyage of The Dawn Treader" and they are translated as "رلة جوابة الفجر" and "الأمير كاسبيان the books are published in 2000 by HarperTrophy (New York, United states of America). They are selected as they are rich with items or expressions that are firmly anchored in English culture. Furthermore, they are translated into Arabic where most of the target readers belong to a conservative culture. Consequently, there are definitely wide array of expressions which can be alien or intolerable in the receiving culture.

\section{B. Research Purpose and Questions}

This study is aimed at examining how problematic cultural-specific items are treated during the process of translation. Trying to understand the way in which such items are dealt with will lead to the ultimate goal that is identifying the most preferable solutions that can be followed when translating children's literature in the Arab world. Hence, this research study seeks to answer the following questions.

1- What are the strategies adopted by the translator in translating culture-specific items in the books under the study?

2- Does the translator make different choices from one book to another in the series? Is there a consistency among the three books under the study?

3- What are the best strategies to translate such culture specific items within fantasy novels?

\section{Data Analysis and Procedure}

In an attempt to answer the previously mentioned research questions, a thorough analysis of the source texts as well as the target texts is conducted. It is intended to mark culture-specific items which are considered a rich source of problems. These items are seen vexing because they are missing in the receiving culture or they have a value that is different from that found in the source culture. Five categories of these culture-bound items are established to serve the goal of this study. These are personal names, mythological creatures, food items, religious expressions and idioms. Various items of each category are extracted and in most cases they are described in order to remove their ambiguity. After that, they are compared with their counterparts in the target text and the translation procedures used to render them are identified based on the theoretical models developed by (Davies, 2003) and (Newmark, 1988). This is followed by the evaluation stage where a number of factors are taken into account such as the advantages and disadvantages of the adopted translation strategy, the abiding by the receiving culture norms and conventions, the suitability to children's level of comprehension and innocence, the effect of the applied translation procedures on the quality of translation, the loss of meaning and aesthetical values or effects created carefully by the original author .The consistency in the followed translation strategies and foreignising or domesticating the target text are considered as well.

\section{TRANSLATION OF CULTURE-BOUND EXPRESSIONS}

\section{A. Language and Culture}

Different nations are noticed to have dissimilar values, beliefs, morals, habits and behavioural conventions which seem to be transmitted from one generation to another. Consequently, it becomes apparent that many cultures exist all over the world and they vary from one place to another. Many scholars define the term "culture" differently which indicates the complexity of such a concept. For Taylor (1871) "culture includes beliefs, arts, skills, moralities, laws, traditions and behaviours that an individual gets from his own society"(p. 1). In the previous definition culture seems to be learned and shared by members of one group. Hofstede (1980) define culture as" the collective programming of the mind which distinguishes the members of one group from another" (p. 21-23). Bruner (1996) views culture as the toolkit for sense-making and communicating. For instance, the user of a language in a particular area is seen as a reflection of that community because language does not consist of merely vocabulary but it can convey the beliefs and 
values of a culture. Hence, Bruner emphasizes the strong relationship between language use and culture. In fact, the meaning may not be grasped appropriately if the cultural context is not taken into consideration. Interestingly, different cultures can have different interpretations of the same symbol. For example, the white colour may be used as a symbol of happiness in some cultures, yet it can stand for sadness in other cultures. In addition, in Muslim communities, saying "in the name of God" at the beginning of each action to receive blessing from God may not be understood if such a language use is translated without its cultural context. Therefore, the linguistic choices of a certain social group are seen to be highly related to its culture and it will be almost impossible to encode such choices if the cultural environment is neglected. It can be noticed that language plays a key role in different societies and cultures since it is seen as the basic instrument by which a particular generation passes on its beliefs and customs to the other (Ilić, 2004, p. 3). In short, language is considered as a way of demonstrating a great deal of cultural norms and conventions that stand behind lots of linguistic practices such as greetings, expressing different kinds of feelings, opening and ending conversations and negotiating. Hence, a wide range of linguistic expressions are noticed to be shaped based on what a particular culture values or devalues.

\section{B. Culture-bound Expressions}

\section{A). Names}

Literary works seem to be full of proper nouns which are usually chosen carefully by the author in order to serve a particular end. Aixela (1996) divides culture-bound items into proper names and common expressions. For him, proper nouns can be split into conventional proper nouns that tend to be meaningless and loaded names by which he means those literary names that appear to be motivated and meaningful. In addition, he argues that names of the first group should be preserved in the translation except in those cases where conventional equivalents can be found in the target language. However, giving linguistic translations to loaded names is seen to be the best solution for him. Different translation strategies are followed to translate personal names and names of mythological creatures in the three selected novels.

\section{a. Personal names \\ Example (1)}

"Once there were four children whose names were Peter, Susan, Edmund and Lucy" (Lewis, 2000 p.3)

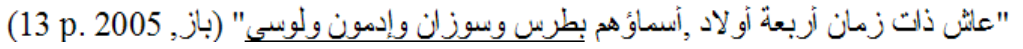

It is noticed that the translator prefers to naturalize the first three personal names. However, he transliterates the personal name "Lucy". The preservation of these foreign names may reduce children's pleasurable reading experience due to their unfamiliarity with them. Nonetheless, naturalizing and transliterating these names are a manifestation of the exotic flavour which can help the reader understand that such events ,beliefs and values found in these kinds of novels seem to exist in another community that is totally different from his/hers.

Example (2)

"Your father Adam's first wife, her they called Lilith" (Lewis, 2000, p.81)

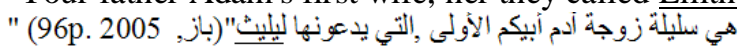

Obviously, the translator uses two strategies to deal with the previously underlined name. He transliterates it and, at the same time, adds extra information as a footnote in order to deal with the ambiguity of this culture- bound item. He states that Lilith is Adam's first wife and she is one of the Jinn who leaves him and gets married to one of the giants. Consequently, Adam suffers from loneliness. Therefore, God sends Eve for him. Although he states that this is a reference to mythology, children may be affected negatively by such kind of information as they will not be knowledgeable enough to distinguish between reality and mythology. Furthermore, not all Muslim children who come across this information will have the chance to know the true story of Adam and Eve due to the fact that the way of bringing children up nowadays is different as most parents tend to be busy in their lives and they do not give much attention to reading the content of children's books to decide if they are good enough for them or not.

b. Names of mythological creatures

Children's stories usually appear to be rich with names of strange creatures which belong to mythological sources found in various cultures. These creatures embody the most important teachings and ideas of a particular society and are intended to transfer such teachings into other generations via the power of vivid imagery. It is worth noting that a great deal of western literature is based on Greek or Roman mythology (Godfrey, 2009, P.11-13).Hence, the child readers in the Arab world may face difficulty to grasp them and the reason which stands behind the presence of such weird creatures in children's narratives. Consequently, this kind of references can be seen as one of the most problematic culture-bound items which require a skilful way of rendering into the target culture. Here are some mythological creatures that are presented in the original texts.

Example (1)

"He was a Faun. And he saw Lucy, he gave such a start of surprise that he dropped all his parcels" (Lewis, 2000, 10)

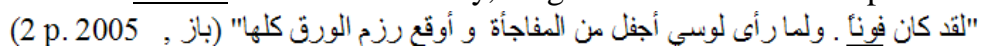

One of the mythical creatures that can be found in the selected novels is the Faun that looks like a man from the waist upward but his legs are shaped like a goat's and instead of feet, he has goat's hoofs. The translator prefers to naturalize this reference in the target text. However, he does not add any extra information to the receptor. Although, there is some kind of description of this mythological creature in the source text that precedes the mention of his exact 
name, the child reader may find such term vague or incomprehensible as he/she may come across such reference for the first time and needs further explanation of this culture-specific item.

Example (2)

"There is no trouble at all now between Telmarines , Dwarfs, Talking Beasts, Fauns and the rest" (Lewis, 2000, p.20)

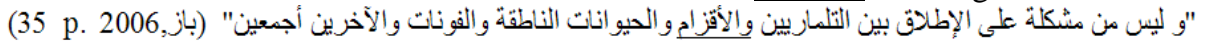

According to Oxford English Dictionary (2017), a dwarf is a member of a mythical race of short, stocky human-like creatures who are usually mentioned in fantasy literature. Literal translation seems to be the translation strategy applied by the translator when rendering the underlined reference. Preserving this item in the target culture will give the impression of unknown creature for the child readers and this can be a case where additional information should be provided. Nonetheless, maintaining such reference in the translated version provides the child with a golden opportunity to be open to other children's stories that exist in totally different cultures which can make him/her learn accept the other in spite of their unfamiliarity with them.

B). Food items

Admittedly, food items differ from one community to another which makes them representative of various cultures. Davies (2003), stresses the importance of food references in children's literature as they help the child to grasp the setting of the novel. Furthermore, they reinforce the credibility of the fantasy as they allow the imaginary part of the story to be built on the real one. Knowing that some food habits are unique to one nation and not to another justifies the fact that what is tolerable in one culture may be intolerable in another which necessitates the careful treatment of this type of culture-bound expressions during the process of translation. In what follows are some instances of how some food items are treated by the translator in the selected novels.

Example (1)

"And I do not see that it brings into the islands meat or bread or beer or wine or timber or cabbages or books or instruments of music or horses or armor or anything else worth having" (Lewis, 2000, p. 59).

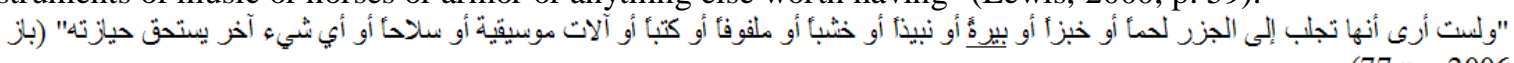

(77 p . 2006

The word "beer" is translated as "بيرة" . The previous item refers to an alcoholic drink made from malt and flavored with hops (Oxford dictionary, 2017). The translation strategy used to render this item seems to be naturalization. The translator's choice to preserve this item helps to show the foreignness of the source text. In addition, keeping such an item in the translated version is important as it is one of the details that helps the reader to distinguish the British context from other contexts. However, preserving such a reference as it is in the target culture may cause some kind of obscurity as the child may not be able to understand the meaning of this word. Therefore, replacing this item with one that is familiar to the receptor is sometimes considered better when it comes to translated children's literature.

Example (2)

"And there were hams and strings of onions hanging from the roof and against the walls were gum boots and oilskins"(Lewis, 2000, p. 73).

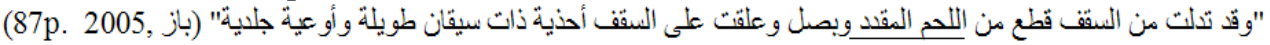

In Islam, pig's meat is prohibited as it has great negative effects on humans' health. Nonetheless, it is very popular in Western cultures. The word "hams" is globalized or replaced with a more neutral or general term that does not belong to a specific culture. The use of such functional equivalent and the avoidance of mentioning the fact that the word "ham" refers to pig's meat makes such reference acceptable to many readers with different cultural backgrounds, yet the receptors will not be able to know the real food item that is closely related to Western cultures. To put it in a nutshell, the translator is successful at preserving the conventions and norms of the Islamic and Arabic culture although such a treatment leads to the loss of the uniqueness of the source culture.

C). Religious expressions:

Since translation is considered a way of transferring the ideas and religious concepts from one society into another, the translation process will be very challenging. There will be many obstacles which need to be overcome especially when people of the two societies embrace two different religions. Religious expressions carry in them some cultural meaning and messages that appear to be unique to a particular community. Therefore, not any language user can understand them except the language native users. Dealing with religious expressions is not an easy task at all as there may be a lack of equivalences in the target culture. In addition, such kind of expressions are sensitive due to their holiness (Khammyseh, 2015).The official Arab translator seems to adopt various translation strategies when dealing with a number of religious expressions.

Example (1)

"By Jove, you are right, said Peter, and look there and there. It's trees all round. And this wet stuff is snow. Why I do believe we've got into Lucy's wood after all " (Lewis, 2000, p. 55).

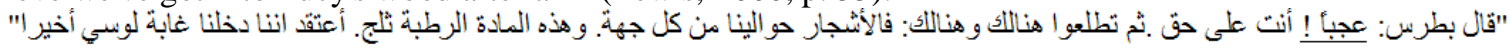

(68 p. 2005, بازب)

According to Oxford English dictionary (2017), Jove refers to a poetical equivalent of Jupiter which is the name of the highest deity of the ancient Romans. This expression seems to be a mild oath which is used to express surprise or emphasis. Clearly, the translator does not preserve such culture-bound expression in the translated version. Instead, he tries to use a functional equivalent for the source language word which shows that he prefers to translate such a 
reference by using a culture-neutral item. The translator's attempt to overcome equivalence problems and cultural diversity by following the previously mentioned strategy seems to be a good one as such rendition does not violate the intended meaning.

Example (2)

"There, far to the East, was something twinkling and moving. "By gum!" whispered Peter to Susan , the sea!"(Lewis, 2000, p. 125)

"فهناك, بعيدأ نحو الثرق, ظهز شيء يتو هج ويتموج. وهمس بطرس لنوزان : صنقيني إنه البحر!" (باز , 141 p. 2005 )

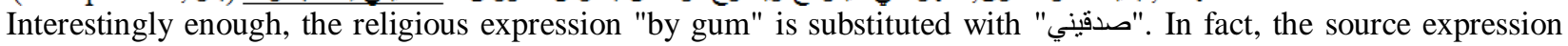
can be used either to express amazement or literally as a kind of swearing. In this context, it seems that such an expression is used by the speaker to prove that what he believes is true. Since the preservation of this exotic expression will not be acceptable to the target readers, let alone its unintelligibility, the translator decides to replace it with a culture-free item. Nonetheless, his rendition causes a kind of effect loss as swearing sounds to indicate the speaker's strong emphasis that he/she tells the truth whereas the translator's soft rendition simply conveys that someone asks another to believe him/her.

D). Idioms

It can be noticed that many languages have fixed expressions whose meanings cannot be inferred from the meaning of the individual words constituting them. These expressions are known as idioms and the way in which they are rendered occupies great significance in literary translation as they may increase the cultural gabs if they are not translated successfully. Since idioms are considered one of the aesthetic devices found in any piece of literary writing, they may be problematic for some translators (Khosravi \& Khatib, 2012). In addition, they are seen as culture-specific items for which the translator may not find a suitable equivalent in the target culture. Translators use a number of translation strategies during the process of rendering idioms in an attempt to bridge the gap between the source as well as the target cultures.

Example (1)

"Mr. Beaver sat down quietly at the edge of the hole, looked hard into it, then suddenly shot in his paw , and before you could say Jack Robinson had whisked out a beautiful trout"( Lewis, 2000, p. 73).

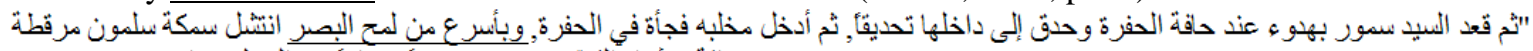

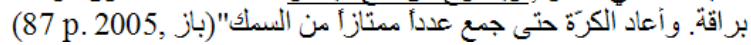

The translator renders the previous idiom into a non-identical idiom in the target culture but one which conveys the same meaning. Since the original idiom represents quickness, the translator can communicate the intended message of the source text expression (Oxford English Dictionary, 2017). In addition, localizing the former idiom contributes a lot to grasping the meaning and appreciating the aesthetical effect experienced by the source text readers.

Example (2)

"Please, your Majesty, said the Fox, we were given them And if I might make so bold as to drink your majesty's very good health"(Lewis, 2000, p. 115).

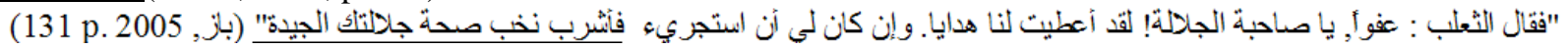

A different translation strategy is followed when rendering "to drink your majesty's very good health" which is translated as "أشرب نخب صحة جلالتك الجيدة". According to Oxford English Dictionary (2017), the previous idiom can be used to express one's good wishes for someone by raising one's glass and drinking a small amount. This concept seems to be totally missing in the Islamic culture. Hence, the translator may paraphrase the meaning as he cannot find an identical idiom in the target culture in both the form and the meaning. However, his used strategy fails to remove the ambiguity posed by such an idiom as the Muslim child reader will not be able to comprehend the intended meaning without additional information due to the absence of such practice in the target culture.

\section{CONCLUSION}

This study aimed at investigating how culture-bound expressions are dealt with in translating from English into Arabic. The fact that the world consists of various cultures which vary from one another leads to facing great challenges during any form of communication among people with different cultural backgrounds. These novels are targeted at children. Translating them into different languages makes them very famous and influential. Since the source texts belong to a language and culture that hold great dissimilarities with the target ones, they are considered to be rich sources of a wide array of perplexing concepts and expressions. The translation strategies adopted to render these intricate references are examined in order to find out to what extent the translator is felicitous as a cultural mediator. Light is spotted on the consequences of the translator's decisions in relation to both the original text as well as the target one. Thus, various aspects of the source and target texts are scrutinized and compared in an attempt to highlight the adequate and inadequate handling of these challenging items and pave the way for producing different literary works of high translation quality.

The first research question is aimed at identifying the strategies used by the translator to deal with the items that seem to be culture-specific. In an attempt to answer this question, different categories of culture-bound expressions are developed. Then, several examples of each category are extracted and the applied translation strategies are identified 
with the help of the analysis models stated in chapter three. The findings of the analyses are discussed in the previous chapter.

The second research question is intended to find out whether there is a kind of consistency among the three books under the study. It is shown in the previous chapter that translation options differ considerably among the three books despite the fact that they are translated by the same translator. Inconsistency in translation is not only found among the categories but also amid different items of the same category.

The research last question tries to find out the best translation strategies that can be followed during the process of translating culture-bound expressions found in fantasy novels targeted at children. In spite of the inconsistency in the used translation strategies, the translator shows a high tendency towards foreignising the target text through retaining a great deal of exotic expressions without any attempt to manipulate them. In some cases, his decisions may be considered reasonable.

Nonetheless, there are other cases where his choices are not justifiable due to the availability of other options that will make the text more accessible to the target child readers. Although domesticating the source culture items can lead to the deformation of the original message and loss of meaning, there seems to be an urgent need for it sometimes. However, the translator should do his best to produce an adequate translation which does not deviate greatly from the original meaning and effects. In fact, being faithful to the source text author or adapting the original items to conform to the conventions and norms of the target culture appear to be a subject of controversy. As translation allows two different worlds to meet, translators should keep in mind the cultural sensitivity of some source items which necessitates their adaptation especially when the receptors are children with a cultural background that sounds to be full of restrictions. Nonetheless, there may be some exotic items which appear not to be loadable with ideological messages. Consequently, they can be retained, yet they should be accompanied with some explicit clarification that will help the child readers to widen their knowledge and at the same time their attention will be drawn to the foreignness of these items. It should be mentioned that fidelity may be sacrificed for the sake of creating the same delight experienced by the original readers. Thereupon, sometimes, domestication can be looked at as the best solution to deal with some problematic culture bound expressions. For instance, presenting foreign dishes in the translated version will fail to make the narrative enjoyable and appealing to the child readers because they are not common in their culture resulting in unequal effect. Unfortunately, there are many instances where the meaning is preserved at the expense of the items' artistic values. Since literary works are usually claimed to be read not only for gaining some kind of knowledge but also for entertaining and experiencing the beauty of language, translators must take these issues into their consideration while translating any piece of literary writing. Furthermore, the significance that each culture-bound expression occupies in both the source and target cultures should be determined in an attempt to help the translator identify the best solutions for rendering them. A compromise that includes the use of domestication and foreignisation translation strategies appears to be the ideal solution. In this way, the translator will keep the exotic flavour of the source language and culture which will contribute to raising children's awareness regarding other cultural peculiarities. He also can make the source texts apprehensible and acceptable to the target audience.

The results of this study can guide a lot of translation practitioners, educators, parents and censors who should guarantee that young readers' books are devoid of any unacceptable translation practices. It can be noticed that young readers' reactions towards various culture-bound items are not considered in this research study. Hence, prospective research studies which include children's responses are recommended.

\section{REFERENCES}

[1] Aixelá, J. F. (1996). 'Culture-specific items in translation'. In Roman Alvarez and M. Carmen-Africa Vidal, (eds.) Translation, Power, Subversion. Toronto: Multilingual Matters Ltd., 52-78.

[2] Ammer, C. (1997). The American heritage ${ }^{\circ}$ dictionary of idioms. Boston: Houghton Mifflin Company.

[3] Atiyya, Z. (2010). Strategies and Motivations in Translated Children's Literature: Defoe's Robinson Crusoe as a Case Study (Master's thesis, an-Najah National University, Nablus, Palestine). Available from: https://scholar.najah.edu/sites/default/files/all-thesis/815.pdf [Accessed on $4^{\text {th }}$ June 2017].

[4] Bassnett, S. (2002). Translation Studies ( $3^{\text {rd }}$ ed). London: Routledge.

[5] Beer. (2017). In oxforddictionaries.com Available from: https://en.oxforddictionaries.com/definition/beer [Accessed on $4^{\text {th }}$ May 2017].

[6] Blessing in disguise. (2017). In cambridge.org Available from: http://dictionary.cambridge.org/dictionary/english/blessing-indisguise [Accessed on $6^{\text {th }}$ May 2017].

[7] Bruner, J. (1996). The culture of education. Cambridge, MA: Harvard University Press.

[8] By Jove (2017). In oxforddictionaries.com Available from: https://en.oxforddictionaries.com/definition/by_jove [Accessed on 4th may 2017].

[9] Davies, E. E. (2003). 'A goblin or a dirty nose? the treatment of culture-specific references in translations of the Harry Potter books'. The Translator, 9(1), 65-100.

[10] Dickman, F. (1999). I can't believe it's a translation. Book Links, 8(3), 22-25.

[11] Drink someone's health, (2017). In oxforddictionaries.com Available from: https://en.oxforddictionaries.com/definition/drink_someone's_health [Accessed on 5th May 2017].

[12] Dwarf. (2017). In oxforddictionaries.com Available from: https://en.oxforddictionaries.com/definition/dwarf [Accessed on $4^{\text {th }}$ May 2017]. 
[13] Elewa, A. (2015). Literary and Cultural Translation. New Vision for Translation Culture.

[14] Giant. (2017). In cambridge.org Available from: http://dictionary.cambridge.org/dictionary/english/giant [Accessed on $5^{\text {th }}$ May 2017].

[15] Giant, (2017). In oxforddictionaries.com Available from: https://en.oxforddictionaries.com/definition/giant [Accessed on 4th May 2017].

[16] God (or goodness or heaven) knows. (2017). In oxforddictionaries.com Available from: https://en.oxforddictionaries.com/definition/god_(or_goodness_or_heaven)_knows [Accessed on $5^{\text {th }}$ May 2017].

[17] Godfrey, L. (2009). Mysteries, legends, and unexplained phenomena: Magical creature. New York: Chelsea House.

[18] Hayes, N., \& Zeece, P. (2004). Books for young children: International children's literature. Early Childhood Education Journal, 32(3), 191-197.

[19] Hofstede, G. (1980). Culture's consequences: International differences in work-related values. London: Sage Publications.

[20] Ilić, B. (2004). Language and culture studies - wonderland through the linguistic looking glass. Facta Universitatis, 3(1), 1-15.

[21] Khammyseh, D. (2015). The problems in translating Islamic expressions in religious occasions. Journal of Education and Practice, 6(35), 103-109.

[22] Khosravi, S. \& Khatib, M. (2012). Strategies used in translation of English idioms into Persian in novels. Theory and Practice in Language Studies, 2(9), 1854-1859.

[23] Lewis, C. S. (2000). Prince Caspian. (S. Baz, Trans.). Amman: Ophir. (2006).

[24] Lewis, C. S. (2000). Prince Caspian. New York: HarperTrophy.

[25] Lewis, C. S. (2000). The Lion, the Witch and the Wardrobe. (S. Baz, Trans.). Amman: Ophir. (2005).

[26] Lewis, C. S. (2000). The Lion, the Witch and the Wardrobe. New York: Harper Trophy.

[27] Lewis, C. S. (2000). The Voyage of The Dawn Treader. (S. Baz, Trans.). Amman: Ophir. (2006).

[28] Lewis, C. S. (2000). The Voyage of The Dawn Treader. New York: Harper Trophy.

[29] Malinowski, B. (1923). The Problem of Meaning in Primitive Languages. In C. K. Ogden, \& I. A. Richards (Eds.), The Meaning of Meaning (pp. 296-336). London: K. Paul, Trend, Trubner.

[30] Marmalade, (2017). In cambridge.org Available from: http://dictionary.cambridge.org/dictionary/english/marmalade [Accessed on $6^{\text {th }}$ May 2017].

[31] Mdallel, S. (2003). Translating children's literature in the Arab World: The state of the Art. Meta, 48(1-2), 298-306.

[32] Mehawesh, M. I. (2014). History of translation in the Arab world: An overview. US-China Foreign Language, 12(8), 684-691.

[33] Newmark, P. (1981). Approaches to Translation. Oxford: Pergamon Press.

[34] Newmark, P. (1988). A textbook of translation. London: Prentice Hall International.

[35] Nida, E. A. \& Taber, C. R. (1969). The theory and practice of translation. Leiden: E.J. Brill.

[36] Nida, E. A. (1964). Toward a Science of Translating. Leiden: E. J. Brill.

[37] Nida, E. A. (2001). Language and Culture-Contexts in Translation. Shanghai: Shanghai Foreign Language Education Press.

[38] Oittinen, R. (2000). Translating for Children. New York: Garland.

[39] Pork, (2017). In oxforddictionaries.com Available from: https://en.oxforddictionaries.com/definition/pork [Accessed on $5^{\text {th }}$ May 2017].

[40] Ratiba, B. (2014). Adaptation in translating children's literature (Master's thesis, University of Kasdi Merbah Ouargla, Ouargla, Algeria). Available from: https://bu.univ-ouargla.dz/master/pdf/bediaf-ratiba.pdf?idmemoire $=4307$ [Accessed on $6^{\text {th }}$ June 2017]

[41] Roll. (2017). In oxforddictionaries.com Available from: https://en.oxforddictionaries.com/definition/roll [Accessed on $6^{\text {th }}$ May 2017].

[42] Russel, J. (2009). Narnia as a site of national struggle: marketing, Christianity, and national purpose, in The Chronicles of Narnia: The Lion, the Witch and the Wardrobe. Cinema Journal, 48(4), 50-76.

[43] Satyr, (2017). In oxforddictionaries.com Available from: https://en.oxforddictionaries.com/definition/satyr [Accessed on 4th May 2017].

[44] Talk the hind leg off the donkey. (2017). In cambridge.org Available from: http://dictionary.cambridge.org/dictionary/english/talk-the-hind-leg-s-off-adonkey?q=\%22+talk+the+hind+leg+off+the+donkey [Accessed on $6^{\text {th }}$ May 2017].

[45] Venuti, L. (1995). The translator's invisibility: A history of translation. London: Routledge.

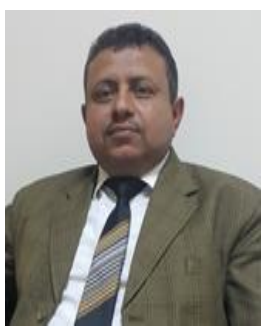

Hussein Ali Habtoor is an associate professor of applied linguistics at the University of Aden, YEMEN. He worked at King Saud University, Riyadh from 2007 till 2009. He is currently in a sabbatical at the University of Najran in KSA as an associate professor of applied linguistics. His interests include Second Language Acquisition, Reading in Second Language Research, Translation Studies and Critical Discourse Analysis. He is an editorial member of a number of international journals and he is currently supervising a number of M.A. research students at the programme of Applied Linguistics at Najran University.

Abrar Abdullah Al-Qahtani is a lecturer at the Department of English at the University of Najran, KSA. She did her M.A. research on Translation Studies at the University of Najran. She is currently preparing for her Ph. D. programme in Translation Studies in UK. Her interests include Translation Theories and Practices, Second language Acquisition Research and Translation Studies. 